\title{
Spatio-temporal trends and body size differences of OCPs and PCBs in Laeonereis culveri (Polychaeta: Nereididae) from Southwest Atlantic estuaries
}

\author{
M. Díaz-Jaramillo*, M.V. Laitano, M. Gonzalez, K.S.B. Miglioranza \\ Instituto de Investigaciones Marinas y Costeras, FCEyN, UNMdP-CONICET, CC1260, 7600 Mar del Plata, Argentina
}

A R T I C L E I N F O

\section{Keywords:}

POPs

Organochlorine

Estuaries

Nereididae

Benthos

GRULAC region

\begin{abstract}
A B S T R A C T
Southwest Atlantic (SWA) estuaries have been historically impacted by industrial and agricultural activities that represent an important source of organochlorine pesticides (OCPs) and polychlorinated biphenyls (PCBs). Intraspecific differences in OCPs and PCBs levels were evaluated in the benthic polychaete Laeonereis culveri from SWA estuaries (Samborombón; Mar Chiquita; Quequén Grande and Bahía Blanca) at different spatio-temporal scales. Regarding inter- and intra-estuarine spatial comparisons polychaetes showed significant differences in OCPs/PCBs levels ( $p<0.05$ ) being DDTs, endosulfan, penta- and hexa-CBs homologues the most representative compounds. Intra-estuarine comparisons also showed significant differences in terms of seasonality and body size $(p<0.05)$. OCPs/PCBs concentrations were negatively correlated with animal weight, but this covariable was not relevant on differences observed. OCPs/PCBs levels in polychaetes showed strong relationships with those of sediments, being suitable for estuarine biomonitoring studies. Seasonal and body-size differences found in OCPs and PCBs levels in tissues reveal the importance of these factors for intra-estuarine monitoring.
\end{abstract}

\section{Introduction}

Persistent organic pollutants (POPs) had an extensive worldwide use in the last century until their prohibition. Many of them remain in several environmental matrices including coastal sediments. Organochlorine pesticides (OCPs) and polychlorinated biphenyls (PCBs) are POPs of environmental concern due to its persistence, toxicity and biomagnification along terrestrial and aquatic trophic webs (Bodin et al., 2008; Burreau et al., 2004; Li et al., 2017). Sediment inhabiting organisms would be exposed to legacy POPs over extended periods, making them useful for biomonitoring studies (Ruus et al., 2002; Nunes et al., 2011; Van Ael et al., 2012, 2013). Nereid polychaetes are common benthic species from soft-bottom sediments, which represent important food supply for estuarine food web and some species had been used as biomonitors of organic pollutants (Ruus et al., 2002; Nesto et al., 2010; Díaz-Jaramillo et al., 2015; Li et al., 2017). The estuarine polychaete Laeonereis culveri (formerly, Laeonereis acuta) is a key estuarine species from Southwest Atlantic (SWA) estuaries and they are used in many fields and laboratory toxicological studies (De Jesús-flores et al., 2016; Díaz-Jaramillo et al., 2016; Sardi et al., 2016).

Particularly, some estuaries in Argentina are located in many crowded and industrial areas, with their catchment area under extensive and intensive agricultural activities (Gonzalez et al., 2013).
Besides, many of these coastal environments serve as nesting and feeding habitats for many species, among other ecosystem services, being protected natural areas of regional and global concern (Kopprio et al., 2015). Several studies reported the occurrence of PCBs and OCPs in sediment, water and vertebrate species from SWA estuaries (Colombo et al., 2005; Gonzalez et al., 2013; Tombesi et al., 2017). However, few studies have focused on benthic invertebrate species (Menone et al., 2001, 2006). Information about OCPs and PCBs levels in key benthic species, as nereids polychaetes, are necessary in order to compare impacted and non- impacted areas as well as the potential risk to other species associated in the estuarine food web.

Inter-estuarine differences in OCPs/PCBs levels of benthic species are expected upon the different anthropogenic pressure on each system. However, for infaunal species, intra-estuarine variability may also be considered. Spatial and temporal trends are important for studies that involve OCPs and PCBs tissue analysis and their intraspecific variability in benthic species (Olenycz et al., 2015; Li et al., 2017). Additionally, when evaluating the use of $L$. culveri as POPs biomonitor, is necessary to consider the influence of age or body size in the intra-estuarine variability, to obtain proper comparisons among sites or estuaries (Burreau et al., 2004; Milun et al., 2016; Viganò et al., 2007).

The aim of this study was to determine OCPs and PCBs levels in $L$. culveri tissues and sediments from Samborombón Bay, Mar Chiquita

\footnotetext{
* Corresponding author.

E-mail address: mdiazjaramillo@conicet.gov.ar (M. Díaz-Jaramillo).
} 
Table 1

SWA estuaries, L. culveri and sediment sampling site description. *Sampling sites for inter-estuarine spatial comparisons, **Sampling sites for intra-estuarine spatial comparisons, ${ }^{* * *}$ Sampling sites for intra-estuarine seasonal comparisons, ${ }^{* * * *}$ Sampling sites for intra-estuarine body weight/size comparisons.

\begin{tabular}{|c|c|c|c|c|}
\hline & Sites & Coordinates & Site Description & Comparisons \\
\hline Samborombón & SAM 1 & $\begin{array}{l}36^{\circ} 19^{\prime} 21^{\prime \prime} \mathrm{S} \\
56^{\circ} 46^{\prime} 26^{\prime \prime} \mathrm{W}\end{array}$ & Tapera de López sector, recreational activities. Protected area. & $*, * *$ \\
\hline Urban \& Agricultural catchment basin & SAM 2 & $\begin{array}{l}36^{\circ} 20^{\prime} 37^{\prime \prime} \mathrm{S} \\
56^{\circ} 44^{\prime} 44^{\prime \prime} \mathrm{W}\end{array}$ & San Clemente del Tuyu Port, boat traffic. Protected area. & $*, * *, * * *$ \\
\hline Mar Chiquita & MCH 1 & $\begin{array}{l}37^{\circ} 44^{\prime} 39^{\prime \prime} \mathrm{S} \\
57^{\circ} 25^{\prime} 23^{\prime \prime} \mathrm{W}\end{array}$ & Mar Chiquita town, recreational activities. Protected area. & $*, * *, * * *, * * * *$ \\
\hline Agricultural catchment basin & MCH 2 & $\begin{array}{l}37^{\circ} 44^{\prime} 22^{\prime \prime} \mathrm{S} \\
57^{\circ} 25^{\prime} 37^{\prime \prime} \mathrm{W}\end{array}$ & Mar Chiquita town, small boat traffic and recreational activities. Protected area. & $*, * *$ \\
\hline Quequén Grande & QQG 1 & $\begin{array}{l}38^{\circ} 33^{\prime} 13^{\prime \prime} \mathrm{S} \\
58^{\circ} 43^{\prime} 29^{\prime \prime} \mathrm{W}\end{array}$ & Necochea city, recreational activities & $*, * *, * * *$ \\
\hline Agricultural catchment basin & QQG 2 & $\begin{array}{l}38^{\circ} 33^{\prime} 44^{\prime \prime} \mathrm{S} \\
58^{\circ} 42^{\prime} 58^{\prime \prime} \mathrm{W}\end{array}$ & Quequén city, boat traffic and recreational activities. & $*, * *$ \\
\hline Bahía Blanca & BBL 1 & $\begin{array}{l}38^{\circ} 44^{\prime} 54^{\prime \prime} \mathrm{S} \\
62^{\circ} 22^{\prime} 57^{\prime \prime} \mathrm{W}\end{array}$ & Cuatreros Port, boat traffic and industrial activities. Protected area. & $*, * *$ \\
\hline Industrial \& Agricultural catchment basin & BBL 2 & $\begin{array}{l}38^{\circ} 44^{\prime} 15^{\prime \prime S} \\
62^{\circ} 18^{\prime} 49^{\prime \prime} \mathrm{W}\end{array}$ & Maldonado sector, recreational and industrial activities. & $*, * *, * * *$ \\
\hline
\end{tabular}

coastal lagoon, Quequén Grande river and Bahía Blanca SWA estuaries. OCP and PCB residues in L. culveri tissues and sediments were analyzed in terms of intra and inter-estuarine differences related to spatiotemporal and size differences.

\section{Material and methods}

\subsection{Study area}

SWA estuaries located in the Pampean biome extends $>1000 \mathrm{~km}$ and are characterized by variable morphology and hydrography (Piccolo and Perillo, 1999) (Table 1). Samborombón estuary (SAM) is a microtidal estuary that corresponds to Samborombón-Salado system; its wetland area was declared a Ramsar site due to its importance for biodiversity conservation (Kopprio et al., 2015). Anthropogenic chemical impacts reported in SAM and adjacent areas are related to eutrophication, heavy metal and OCPs pollution (Colombo et al., 2005; Kopprio et al., 2015). Mar Chiquita estuary (MCH) is a microtidal coastal lagoon, which receives freshwater inputs from many streams of the wet Pampean region and was declared Man and the Biosphere Reserve by UNESCO (Beltrame et al., 2009). Agricultural and recreational activities in the lagoon and adjacent areas represent the main threats. POPs and heavy metals were observed in particulate material and sediments (Menone et al., 2001; Beltrame et al., 2009; Díaz-Jaramillo et al., 2016). The Quequén Grande estuary (QQG) is a partially mixed microtidal estuary surrounded by an important port area. QQG also receives important inputs of OCPs and other pesticides derived from extensive agricultural activities in its watershed and other compounds from Necochea and Quequén cities (Gonzalez et al., 2013; Kopprio et al., 2015; Silva Barni et al., 2014; Lupi et al., 2015). Bahía Blanca (BBL) is a mesotidal estuary located in the south of the study area. This larger estuarine system $\left(3000 \mathrm{~km}^{2}\right)$ comprises different anthropogenic activities, in conjunction with preservation areas of regional and global concern (Kopprio et al., 2015). Urban activities, petrochemical industries, maritime traffic and sewage discharges represent the main pollution threats. OCPs, petroleum-related hydrocarbons, heavy metals and organotin compounds were reported in sediments and biota from this SWA estuarine environment (Marcovecchio and Ferrer, 2005; Menone et al., 2006; Delucchi et al., 2007; Tombesi et al., 2017).

\subsection{Sampling}

Two sites were sampled in each estuarine area during the warm season (December-January) according to the occurrence of $L$. culveri on intertidal sediments for inter-estuarine comparisons (Table 1). Intraestuarine seasonal trends in the OCPs and PCBs levels in L. culveri were assessed by the additional sampling of one site from each estuarine system in cold seasons (June-July) (Table 1). For intra-estuarine comparisons, intraspecific size differences were performed by obtaining polychaetes from the same sampling site (Table 1$)$. Three sizes were defined according to the wet weight of individuals: large $(\approx 0,70 \mathrm{~g} /$ $70 \mathrm{~mm})$, medium $(\approx 0,25 \mathrm{~g} / 40 \mathrm{~mm})$ and small $(\approx 0,05 \mathrm{~g} /<20 \mathrm{~mm})$. Three composite samples were obtained $(n=3)$ considering the most common size in each estuarine site. Polychaeta composites of 3,5 or 15 individuals were made from large, medium and small individual, respectively. Each individual of $L$. culveri was manually removed from the sediments and subject to $24 \mathrm{~h}$ purge in filtered, diluted seawater (20 PSU) to eliminate recently ingested sediments. Surface sediments $(0-10 \mathrm{~cm}$ deep) were obtained in each sampling site $(n=3)$ using metallic core. Tissue composites and sediments were frozen at $-20^{\circ} \mathrm{C}$, until chemical analysis. Samples of $L$. culveri individuals from estuarine preservation areas (Table 1) were taken with permission from OPDS 2145-12776/16 (Organismo Provincial de Desarrollo Sostenible, Buenos Aires, Argentina).

\subsection{Sediment physico-chemical characterization}

Total organic carbon in estuarine sediment was determined by the wet-oxidation method described by Mingorance et al. (2007).

\subsection{OCPs and PCBs analysis}

\subsubsection{Sample preparation}

Sediments $(8-10 \mathrm{~g})$ and polychaete tissues $(0.5-1.5 \mathrm{~g})$ were homogenized with sodium sulfate and Soxhlet extracted $(8 \mathrm{~h})$ with a mixture of hexane-DCM (1:1). All samples were spiked with $20 \mathrm{ng}$ of PCB \#103 as internal standard. Extracts were subsequently concentrated to $2 \mathrm{~mL}$. Polychaete tissue extracts included a lipid removal step by gel permeation chromatography (GPC, Bio Beads S-X3, 200-400 mesh, BioRads Laboratory, Hercules, USA) followed by the gravimetric calculation of lipid percentage (Metcalfe and Metcalfe, 1997). The cleanup of polychaete tissues and sediments was carried out using activated silica gel $\left(200{ }^{\circ} \mathrm{C}, 24 \mathrm{~h}\right)$ conditioned with $10 \mathrm{~mL}$ of hexane and eluted with $10 \mathrm{~mL}$ of a mixture of hexane:DCM (1:1) (Gonzalez et al., 2013). Extracts were then evaporated with $\mathrm{N}_{2}$ to incipient dryness and reconstituted in $500 \mu \mathrm{L}$ of hexane prior to the analysis. Sulfurs impurities were eliminated from sediment extracts by reaction with pre-activated copper particles (Metcalfe and Metcalfe, 1997).

\subsubsection{Analysis of OCPs/PCBs}

OCPs and PCBs were analyzed using a gas chromatograph with an electron capture detector (GC-ECD, Shimadzu 17-A, Japan) using a SPB- 
5 capillary column (Supelco, Bellefonte, PA, USA) and following the method procedures described by Miglioranza et al. (2003). A OCPs mixture (Ultra Scientific North Kingstown, RI, USA) and PCB mixture (Accustandard Absolute Standards, INC, CT, USA) were used for identification and quantification of single compounds. OCPs analyzed were HCHs ( $\alpha-, \beta-, \gamma$ - and $\delta$-isomers); Chlordanes ( $\alpha$ - and $\gamma$-isomers and transnonachlor), Heptachlors (Heptachlor and heptachlor epoxide); DDTs ( $p, p^{\prime}$-DDT, $p, p^{\prime}$-DDE and $p, p^{\prime}$-DDD), Dieldrin and Endosulfans $\alpha$-, $\beta$-isomers and endosulfan sulfate. PCBs analyzed were grouped according to main homologue groups: tetra-CBs ( $\# 44$ and 52); penta-CBs (\#95,101,105,110 and 118); hexa-CBs (\#138,149 and 153) and heptaCBs (\#180).

\subsection{3. $Q A / Q C$ procedures}

In order to detect any contaminant or interference on samples during laboratory handling, procedural blanks (laboratory and instrumental) were included. Recoveries, calculated from spiked blanks and matrices, run by triplicated at $20 \mathrm{ppb}$, were $>90 \%$ with relative standard deviation (RSD) values lower than $15 \%$. Instrumental detection limits, calculated according to Keith et al. (1983), ranged between 0.03 and $0.05 \mathrm{ng} \mathrm{mL}^{-1}$ for HCHs and between 0.08 and $0.33 \mathrm{ng} \mathrm{mL}^{-1}$ for the rest of the compounds (Chlordanes, Heptachlors, DDTs, Dieldrin, Endosulfans and PCBs). Method detection limits for sediments and biota ranged between 0.003 and $0.005 \mathrm{ng} / \mathrm{g}$ for HCHs and between 0.008 and $0.033 \mathrm{ng} / \mathrm{g}$ for the rest of OCPs and PCBs.

\subsection{Data analysis}

In general, both intra- and inter-estuarine OCPs and PCBs differences in $L$. culveri tissues were evaluated by analysis of variance (ANOVA) followed by a Newman-Keuls test for post hoc comparisons $(\alpha: 0.05)$. Data were checked to meet the assumptions of normality and homogeneity of variances before analysis. Data without a normal distribution were analyzed by Kruskal Wallis non-parametric test. Due to different mean weight observed in L. culveri from different estuaries and sites (Fig. S1) we included different analysis to determine the influence of this variable in OCPs and PCBs levels observed in polychaete tissues. OCPs/PCBs levels in tissue versus size relationships and polychaetesediment relationships made with sediment OCPs/PCBs levels versus OCPs/PCBs levels in tissue were evaluated using Pearson $\left(R_{p}\right)$ and Spearman $\left(R_{s}\right)$ correlation analysis for parametric and non-parametric data respectively. Also if the average size as covariable has possible effect in the differences observed ( $\alpha$ : 0.05), an analysis of covariance (ANCOVA) was used. All statistical analysis was performed using the software INFOSTAT.

\section{Results}

\subsection{OCPs and PCBs in sediments}

Organic carbon percentage in estuarine sediments ranged from 0.28 to 0.88 (Table 2). Sediments from different estuarine areas showed total
OCPs values ranging from 0.41 to $1.73 \mathrm{ng} / \mathrm{g}$ d.w whereas total PCBs varied from 0.17 to $0.92 \mathrm{ng} / \mathrm{g}$ d.w (Table 2). Regarding OCPs, sediments from SAM 1 and BBL 1 showed the highest values whereas MCH1 and QQG2 exhibited lower values (Table 2). In general, OCPs in estuarine sediment were dominated by DDTs followed by Endosulfans groups (Table 2). In terms of DDTs, $p, p^{\prime}$-DDD and $p, p^{\prime}$-DDE were the most abundant compounds, with levels between 33 and $91 \%$ of total DDTs in sediments (data not showed). DDD $>$ DDE $>$ DDT was the most common pattern observed in estuarine sediments. Total PCBs levels in sediments showed the highest values at SAM 2 and BB1 whereas MCH1 and MCH2 showed the lowest total PCBs values. Regarding PCBs homologues, Hexa-CBs were the most abundant homologues observed in sediments from SWA estuaries (Table 2). Hexa-CBs were dominated by $\# 153$ congener, which represented $>80 \%$ of total Hexa-CBs in most sediments (Table S1). In winter, estuarine sediments showed similar trends concerning OCPs and PCBs patterns (Table S2). In particular, OCPs from SAM2 showed differences compared to summer season mainly related to the increase of Endosulfans and DDTs concentrations on winter.

\subsection{OCPs and PCBs in L. culveri}

\subsubsection{Inter-estuarine comparisons}

OCPs and PCBs levels in $L$. culveri tissues showed inter-estuarine differences (Table 3, Fig. 1). In this sense, individuals from $\mathrm{MCH}$ and QQG had significantly lower total OCP levels than those from SAM and BBL ( $\Sigma$ OCPs, $p<0.05$, Table 3, Fig. 1a). DDTs and Endosulfans were the most dominant OCPs and showed different inter-estuarine patterns. DDTs in L. culveri tissues showed a similar pattern between MCH and SAM individuals while QQG and BBL polychaetes showed significant lower and higher DDTs tissue levels, respectively ( $p<0.05$, Fig. 1a). In general, DDTs exhibited a similar pattern to those observed in sediments (DDD > DDE > DDT) where DDD was the most abundant metabolite (Data not showed). Different trends were observed in QQG where polychaetes exhibited a DDD $>$ DDT $>$ DDE distribution pattern. Endosulfan tissue levels showed no significant differences among estuaries ( $p>0.05$, Table 3$)$. Endosulfan tissues were dominated by $\beta$ Endosulfan, representing 67 to $89 \%$ of total Endosulfan in $\mathrm{MCH}$ and QQG and 51 to $100 \%$ in SAM and BBL polychaetes.

Regarding inter-estuarine comparison, PCBs levels in polychaetes showed similar patterns to those observed in $\Sigma$ OCPs, where individual from MCH and QQG exhibited significant lower values than those from SAM and BBL $(p<0.05$, Table 3, Fig. 1b). Penta- and Hexa-CBs were the most abundant homologues observed in polychaete tissues (Fig. 1b). Penta-CB homologues were represented mainly by \#101 and \#118 congeners in $\mathrm{MCH}$ and QQG respectively, whereas in SAM and BBL \#95, \#101 and \#110 were the most abundant PCBs (Table S3). HexaCBs were dominated by \#153 representing $>80 \%$ of total Hexa-CBs homologues followed by \#138 (Table S3). Penta-CB congeners followed the pattern observed in $\Sigma$ PCBs $(p<0.05$; Table 3 ) while Hexa-CB homologues showed no significant differences among estuaries $(p>0.05 ;$ Table 3$)$. In general, no significant differences were

Table 2

Organic carbon \%, OCP groups and PCB homologues in sediments (ng/g d.w) from different SWA estuaries and sites.

\begin{tabular}{|c|c|c|c|c|c|c|c|c|c|c|c|c|c|c|}
\hline Estuary & Site & $\%$ OC & OCPs & & & & & & & PCBs & & & & \\
\hline & & & $\mathrm{HCHs}$ & Chlor & End & DDTs & Hepta & Dieldrin & $\Sigma \mathrm{POCs}$ & Tetra-CBs & Penta-CBs & Hexa-CBs & Hepta-CBs & $\Sigma$ PCBs \\
\hline \multirow[t]{2}{*}{ Samborombón } & SAM 1 & 0.28 & 0.03 & 0.14 & 0.18 & 0.70 & N.D & 0.02 & 1.10 & 0.19 & 0.15 & 0.30 & N.D & 0.64 \\
\hline & SAM 2 & 0.50 & 0.12 & 0.10 & 0.08 & 0.40 & 0.03 & N.D & 0.71 & 0.10 & 0.30 & 0.40 & 0.14 & 0.92 \\
\hline \multirow[t]{2}{*}{ Mar Chiquita } & MCH 1 & 0.30 & 0.03 & 0.03 & 0.03 & 0.30 & 0.002 & 0.008 & 0.41 & 0.02 & 0.01 & 0.12 & 0.006 & 0.17 \\
\hline & MCH 2 & 0.37 & 0.01 & 0.007 & 0.13 & 0.31 & 0.01 & 0.009 & 0.49 & 0.02 & 0.03 & 0.16 & 0.009 & 0.23 \\
\hline \multirow[t]{2}{*}{ Quequén Grande } & QQG 1 & 0.58 & 0.03 & 0.03 & 0.15 & 0.38 & 0.007 & 0.02 & 0.64 & N.D & N.D & 0.26 & 0.14 & 0.40 \\
\hline & QQG 2 & 0.88 & 0.07 & 0.07 & 0.09 & 0.18 & 0.01 & 0.04 & 0.46 & 0.15 & 0.11 & 0.27 & N.D & 0.54 \\
\hline \multirow[t]{2}{*}{ Bahía Blanca } & BBL 1 & 0.34 & 0.03 & 0.06 & 0.06 & 1.53 & 0.02 & 0.02 & 1.73 & 0.22 & 0.10 & 0.25 & 0.13 & 0.72 \\
\hline & BBL 2 & 0.28 & 0.04 & 0.03 & 0.15 & 0.22 & 0.02 & 0.03 & 0.50 & 0.10 & 0.11 & 0.43 & 0.005 & 0.66 \\
\hline
\end{tabular}


Table 3

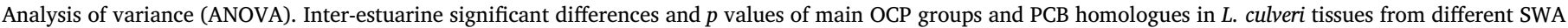

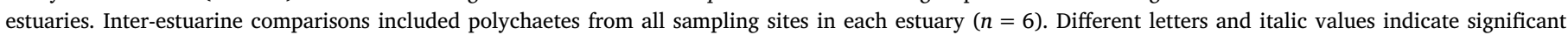
differences between estuaries $(p<0.05)$.

\begin{tabular}{|c|c|c|c|c|c|c|}
\hline \multirow[t]{2}{*}{ Estuary } & \multicolumn{3}{|l|}{ OCPs } & \multicolumn{3}{|l|}{ PCBs } \\
\hline & $\Sigma$ POCs & DDTs & Endosulfan & $\Sigma$ PCBs & Penta-CBs & Hexa-CBs \\
\hline Samborombón & $\mathrm{a}$ & $\mathrm{ab}$ & a & a & a & a \\
\hline Mar Chiquita & $\mathrm{b}$ & $\mathrm{b}$ & $\mathrm{a}$ & $\mathrm{b}$ & $\mathrm{b}$ & $\mathrm{a}$ \\
\hline Quequén Grande & $\mathrm{b}$ & $\mathrm{c}$ & $\mathrm{a}$ & $\mathrm{b}$ & $\mathrm{b}$ & $\mathrm{a}$ \\
\hline Bahía Blanca & $\mathrm{a}$ & $\mathrm{a}$ & $\mathrm{a}$ & $\mathrm{a}$ & $\mathrm{a}$ & $\mathrm{a}$ \\
\hline$p$ value & 0.0025 & $<0.0001$ & 0.0681 & 0.0052 & 0.0003 & 0.2574 \\
\hline
\end{tabular}

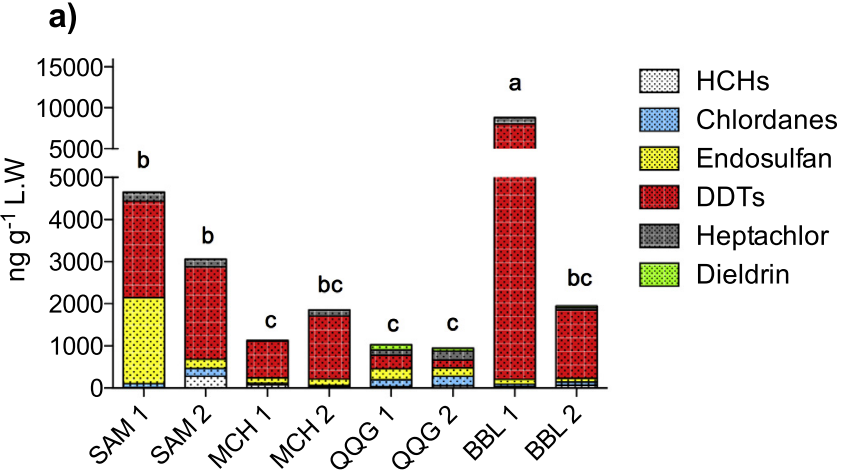

b)

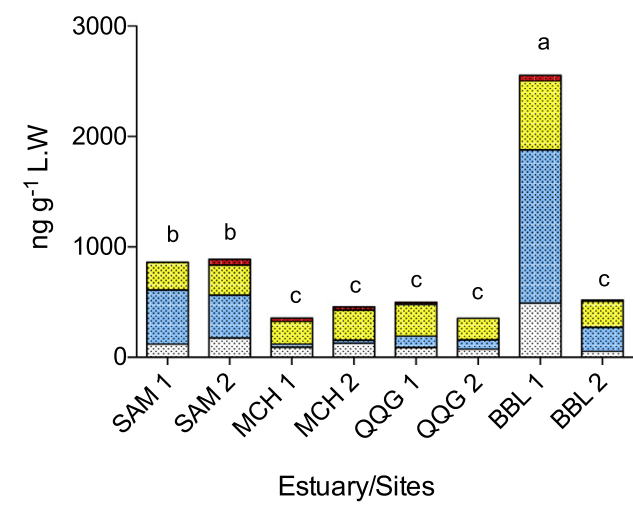

Fig. 1. Inter- and intra-estuarine spatial concentrations of a) OCP groupsand b) PCB homologues in L. culveri tissues from different SWA estuaries and sites. The same letter indicates the absence of significant differences between estuaries and sites $(p>0.05)$.

observed in polychaeta tissue lipid percentage among estuaries and intra-estuaries sites $(p>0.05)$, except for differences observed between SAM 2 and MCH 2 polychaetes ( $p<0.05$; Data not showed).

\subsubsection{Intra-estuarine comparisons}

Intra-estuarine spatial comparisons revealed no significant differences in OCPs and PCBs levels of $L$. culveri tissues within sites in SAM, MCH and QQG estuaries ( $p>0.05$, Fig. 1a, b). However, in BBL individuals from site 1 (BBL1) exhibited significantly higher levels $(p<0.05$, Fig. 1a, b) than those from site 2 (BBL2). Such differences were related to DDTs and Hexa-CBs (Fig. 1a, b).

Seasonal intra-estuarine differences on both total OCPs and PCBs levels were observed in $L$. culveri individuals from SAM and QQG estuaries ( $p<0.05$, Table 4, Fig. 2a, b) being attributable to significant increments of Endosulfan at SAM in winter and DDTs at QQG in summer $(p<0.05$, Table 4). Particularly, higher DDTs levels in summer at QQG were due to a dominance of DDT instead of DDD. Even though $\mathrm{MCH}$ showed no significant seasonal differences in terms of total OCPs ( $p>0.05$, Fig. 2 a), DDTs levels did significantly decrease in winter compared to summer season $(p<0.05$, Table 4$)$. Regarding PCBs levels, the seasonal differences observed at SAM and QQG were related to Penta and Hexa-CB homologues, respectively $(p<0.05$, Table 4). Significant higher levels of Penta-CBs homologues at SAM on winter were related to the presence of \#95, \#110 and \#118. Differences of Hexa-CBs homologues from QQG on winter were related to the decrease of \#153 and \#138 levels in L. culveri tissues (Data not showed). No significant seasonal differences on polychaeta tissue lipid percentage were observed in MCH, QQG and BBL polychaete tissues $(p>0.05)$. On the other hand, a significant increment in tissue lipid percentage on winter was observed in SAM polychaetes $(p<0.05)$.

Intra-estuarine size differences were observed when compared OCPs and PCBs levels among individuals from the same estuarine site $(p<0.05$, Fig. 3a, b). In general small individuals showed significantly higher values of both total OCPs and PCBs levels when compared to medium and large individuals $(p<0.05$, Fig. 3a, b). No significant differences were observed comparing medium and large individuals ( $p>0.05$, Fig. 3a, b). The higher levels of OCPs in small individuals were due to higher values of DDTs and HCHs $(p<0.05$, Fig. 3a). DDTs in all size individuals were dominated by DDD, which represented $>$ $80 \%$ of total DDTs. $\gamma$-HCHs represented the $100 \%$ of $\mathrm{HCHs}$ in all samples. PCBs levels in small polychaetes were significantly higher due to higher levels of Tetra-CB congeners compared to medium individuals and higher levels of Hexa- and Penta-CB homologues compared to both medium and large individuals $(p<0.05$, Fig. $3 b)$. Penta-CBs homologues were dominated by \#101 and Hexa-CBs homologues were dominated by \#153 (> 75\%) followed by \#138 (Table S3). No significant differences were observed in polychaeta lipid percentages for different size class individuals $(p>0.05)$.

\subsection{OCPs and PCBs-weight relationships}

Mean weight of individuals from the studied estuaries showed significant differences, being polychaetes from SAM 1 and BBL smaller than those from the other estuaries and sites $(p<0.05$; Fig. S1a). Seasonal differences in terms of weight of individuals showed differences only in MCH $(p<0.05$; Fig. S1b). Lipid percentage was not correlated with the weight of individuals $\left(\mathrm{R}_{\mathrm{s}}=0.27 ; p>0.05\right)$. Inter and intra-estuarine spatial comparisons showed negative relationships between $\log$ based weight of individuals and lipid basis $\Sigma$ OCPs $\left(\mathrm{R}_{\mathrm{s}}=-0.56 ; p<0.05\right)$ and $\Sigma \mathrm{PCBs}\left(\mathrm{R}_{\mathrm{s}}=-0.51 ; p<0.05\right)$. Intraestuarine weight relationships showed a significant negative correlation between the weight of individuals and $\Sigma$ OCPs $\left(\mathrm{R}_{\mathrm{p}}=-0.78 ; p<0.05\right)$ and $\Sigma$ PCBs $\left(\mathrm{R}_{\mathrm{p}}=-0.85 ; p<0.05\right)$. On this basis DDTs $\left(\mathrm{R}_{\mathrm{p}}=-0.83\right.$; $p<0.05)$ and Hexa-CBs homologues $\left(\mathrm{R}_{\mathrm{p}}=-0.78\right.$; $\left.p<0.05\right)$ were the most inversely correlated compounds. However, ANCOVA analysis made with the weight of individuals, as covariable reflected no significant influence in terms of spatial and seasonal OCPs and PCBs levels observed in L. culveri tissues ( $p>0.05$; Table S4). 
Table 4

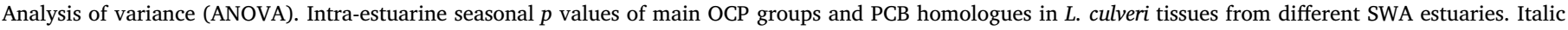
values indicate significant differences between seasons $(p<0.05)$.

\begin{tabular}{|c|c|c|c|c|c|c|}
\hline \multirow[t]{2}{*}{ Estuary } & \multicolumn{3}{|l|}{ OCPs } & \multicolumn{3}{|l|}{ PCBs } \\
\hline & $\Sigma$ POCs & DDTs & Endosulfan & $\Sigma$ PCBs & Penta-CBs & Hexa-CBs \\
\hline Samborombón & 0.0092 & 0.8528 & 0.0057 & 0.0001 & 0.0001 & 0.2998 \\
\hline Mar Chiquita & 0.1000 & 0.0384 & 0.7533 & $>0.999$ & $>0.999$ & $>0.999$ \\
\hline Quequén Grande & 0.0001 & 0.0044 & 0.0063 & 0.0047 & 0.1130 & 0.0036 \\
\hline Bahía Blanca & 0.7000 & 0.6289 & 0.4882 & 0.0777 & 0.5577 & 0.0534 \\
\hline
\end{tabular}

a)
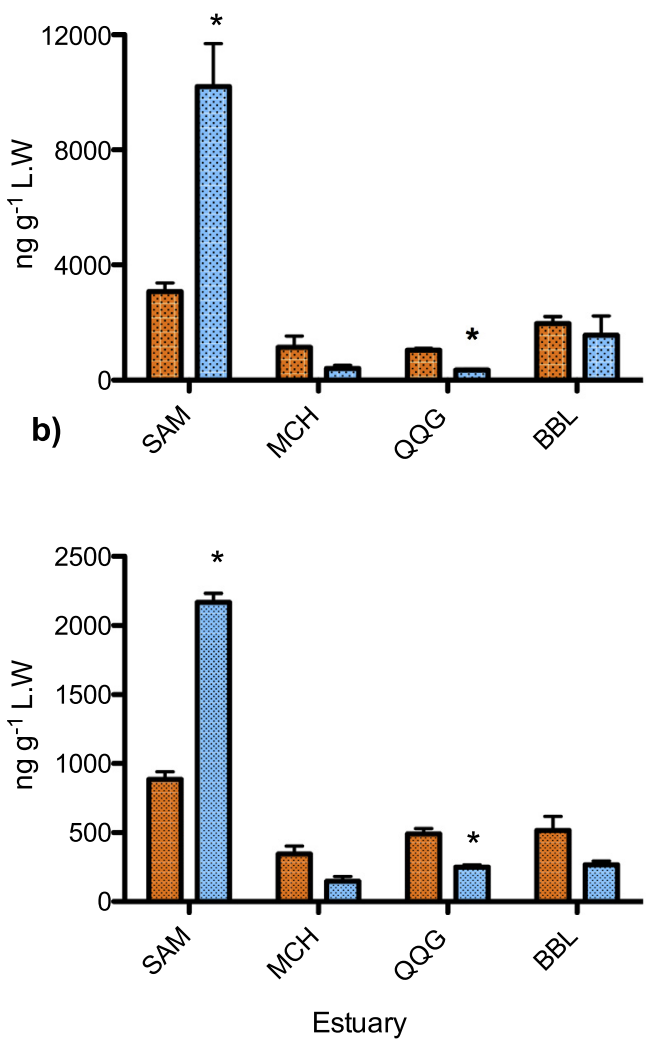

Fig. 2. Intra-estuarine seasonal concentrations of a) OCPs and b) PCBs in $L$. culveri tissues from different SWA estuaries. Asterisk indicates seasonal significant differences $(p<0.05)$.

\subsection{OCPs and PCBs-sediment-polychaete relationships}

Relationships on OCPs and PCBs levels between sediment (ng/g OC) and polychaete tissues (ng/ g lipid) showed different patterns. $\Sigma$ OCPs sediment levels presented a strong positive relationship with $L$. culveri OCPs tissue levels $\left(\mathrm{R}_{\mathrm{p}}=0.91 ; p<0.05\right)$. In particular, DDTs showed a significant positive relationship $\left(\mathrm{R}_{\mathrm{p}}=0.82 ; p<0.05\right)$ whereas Endosulfan presented only a weak correlation between both matrixes $\left(\mathrm{R}_{\mathrm{p}}=0.32 ; p>0.05\right)$. $\Sigma$ PCBs sediment levels from the different estuaries and sites also showed positive relationships with polychaete tissues levels $\left(\mathrm{R}_{\mathrm{p}}=0.74 ; p<0.05\right)$. Regarding PCBs homologues, hexaCBs homologues showed poor sediment-polychaete relationships $\left(\mathrm{R}_{\mathrm{p}}=0.26 ; p>0.05\right)$ whereas Penta-CBs homologues showed a significant positive relationship $\left(\mathrm{R}_{\mathrm{p}}=0.87 ; p<0.05\right)$.

\section{Discussion}

OCPs levels observed in L. culveri from SWA estuaries are different compared to levels found in other nereid species worldwide. In terms of a)

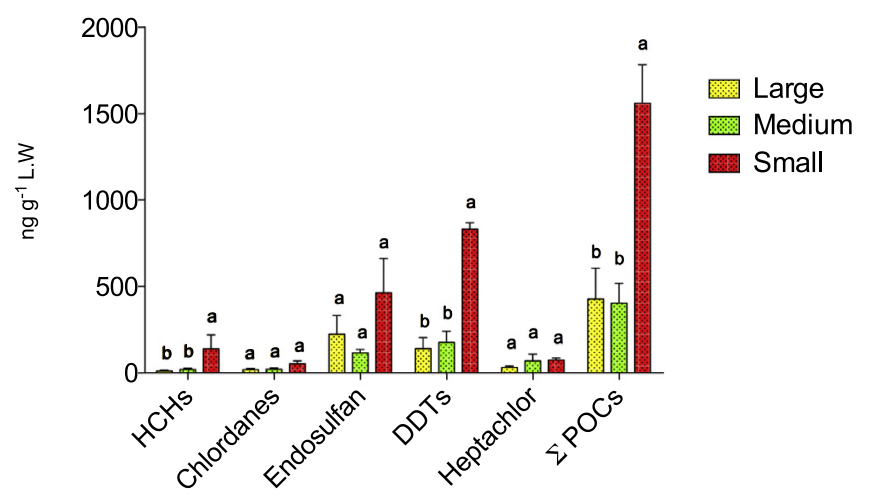

b)

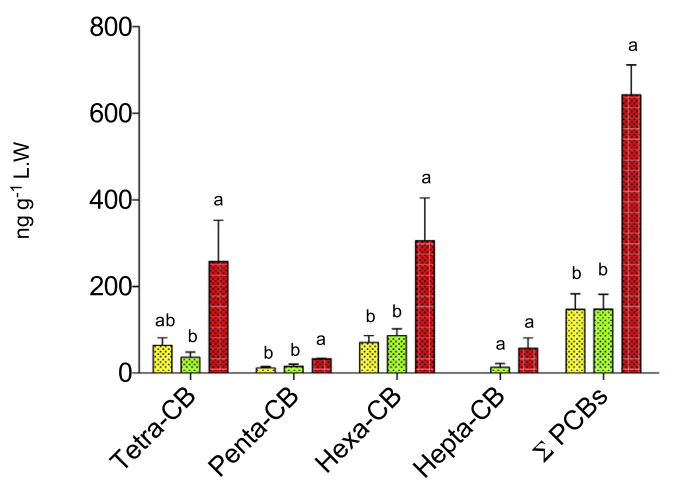

Fig. 3. Intra-estuarine size concentrations of a) OCP groups and b) PCB homologues in $L$. culveri tissues. The same letter indicates the absence of significant differences between estuaries and sites $(p>0.05)$.

total DDTs, L. culveri reported similar (QQG) or higher (SAM, MCH, $\mathrm{BBL}$ ) levels compared to other nereid polychaetes from european coast (Ruus et al., 2002; Van Ael et al., 2013). In addition, DDTs levels observed in Nereis succinea tissues from Hailing bay, China are comparative higher or similar to polychaetes from BBL estuary (Li et al., 2017). Moreover, the DDD predominance observed in L. culveri tissues is in agreement with the results in $N$. succinea. The high metabolic capacity to transform DDT in DDD ( $>86 \%$ ) and direct uptake from the sediment would account for this high DDD accumulation in polychaete tissues (Wang et al., 2015). In addition, it could be also related to high excretion and/or avoidance capability to ingest toxic forms of DDTs in sediments (Lotufo et al., 2000; Wang et al., 2015). Moreover, the predominance of DDD in SWA estuarine sediments suggests higher DDT dechlorination to DDD under anaerobic conditions due to the characteristics of these muddy sand sediments (Lin et al., 2009). Less DDD predominance and more contribution of DDT and DDE observed in both sediment and polychaete from QQG suggest the persistence of new DDT inputs from this watershed to the estuarine area. The use of Dicofol acaricide as a DDT source was indicated in previous works for this area (Gonzalez et al., 2013, Silva Barni et al., 2014). Moreover, a more 
oxygenated condition will contribute to dehydrogenation of DDT to DDE, suggesting therefore a lower anoxic condition in QQG sediments (Yu et al., 2011).

In terms of PCBs congeners observed in L. culveri tissues, SWA estuaries reported low levels compared to Nereid polychaetes from the european estuaries. On this basis, PCB \#101, \#153, \#138 and \#180 levels in L. culveri (ng/g d.w.) are comparatively low considering Nereis diversicolor and Perinereis rullieri from Scheldt estuary and Venice lagoon respectively (Nesto et al., 2010; Van Ael et al., 2012, 2013). In relation to PCBs homologues, Hexa- and Penta-CBs predominance in $L$. culveri tissues is according to other works where Hexa- and Penta-CBs homologues were the main PCBs congeners found in polychaeta species (Goerke and Weber, 1990, 2001; Ruus et al., 2002; Nesto et al., 2010; Hong et al., 2011). This predominance could be due to low elimination rates of this type of PCBs congeners observed in nereid polychaetes compared to other benthic species (Goerke and Weber, 2001). In addition, the predominance of \#153 and \#138 among Hexa-CBs homologues is in accordance with other authors, which indicate that PCB-153 is one of the most common and recalcitrant congeners in biota (Kannan et al., 1995; Bodin et al., 2008; Nesto et al., 2010).

Inter-estuarine differences observed in both OCPs and PCBs levels mainly reflected watershed land use and/or the vicinity of past or current industrial activity in SWA estuaries. In this context, SAM and BBL showed the highest OCP and PCBs levels in both matrixes, which would be related to the high industrial activity and continuous discharges via small tributaries of untreated effluents from high-density urban areas (Colombo et al., 2005; Tombesi et al., 2017). In contrast, MCH and QQG showed lower OCPs and PCBs levels in sediments than in polychaetes that could reflect more distant discharge sources and the dilution effect due to the increasing mixing with seawater (Van Ael et al., 2013). However, the diversity of OCPs observed in QQG reflected the impact of the historical use of old and recently banned pesticides by intensive agricultural activities (Gonzalez et al., 2013). Intra-estuarine spatial differences observed in BBL sites would be related to the big area covered by BBL estuary (Piccolo and Perillo, 1999). The different anthropogenic impact and land use along such area would lead to varying levels of pollutants in its sediments (Tombesi et al., 2017).

Seasonal intra-estuarine OCPs and PCBs analysis showed different patterns among the studied estuaries. In SAM, the significant increment of contaminant levels in polychaete tissues during winter was related to differences observed in lipid percentage and partly to OCPs and PCBs increase in close sediments. A winter increment of OCPs and PCBs levels was also found in other aquatic species (Milun et al., 2016), and it is often associated with changes in the inputs of organic contaminants from diffuse sources in the whole watershed by precipitation and runoff process (Nyberg et al., 2015). In addition, seasonal lipid differences may be related to physiological fluctuations observed in some nereid species by changes in gametogenic cycle and diet (Luis and Passos, 1995). However, seasonal OCPs and PCBs trends in L. culveri from the remaining estuarine systems showed generally similar or lower values in the cold season compared to summer. No seasonal differences on lipid percentage levels observed in $L$. culveri could be in part an explanation to such small seasonal differences in OCPs and PCBs levels, as observed in other aquatic species (Greenfield et al., 2005). Intra-estuarine size or weight differences observed in L. culveri are according to Viganò et al. (2007) who noted that small individuals of amphipods accumulate significant higher levels of OCPs and PCBs compared to large individuals. However, some authors observed inverse relationships in aquatic species since large individuals accumulated significant higher OCPs concentrations compared to small ones, associated to higher intake and aging (Olsson et al., 2000; Burreau et al., 2004). The absence of lipid percentage differences in our results and the similar OCPs absorption efficiency reported between large and small nereids (Ahrens et al., 2001), make it difficult to establish a relationship with these factors. On this basis, differences in diet preferences observed in juveniles compared to adults Nereids polychaetes, and growth dilution effects could be a reasonable explanation to our findings (Ahrens et al., 2001; Viganò et al., 2007).

The absence of a significant influence of the weight of individuals as covariable on inter-estuarine spatial and seasonal OCPs and PCBs differences observed reveals the existence of extrinsic factors influencing OCPs and PCBs accumulation in L. culveri. Nevertheless, the higher OCPs and PCBs accumulation on smaller individuals could be related to the fact that some nereid species from polluted estuaries reached lower sizes than polychaetes from low polluted areas (Durou et al., 2007). Small individuals with high OCPs and PCBs levels as observed in SAM 1 and BBL 1 could be due to toxicant effects of pollutants in the decrease of the energy available for growth (Durou et al., 2007; Díaz-Jaramillo et al., 2015). Furthermore, the positive sediment-tissue relationship for $\Sigma O C P$, DDTs, $\Sigma$ PCBs and Penta-CBs homologues indicate the effective use of $L$. culveri as a biomonitor of these contaminants in estuarine sediments with an important legacy of these banned pollutants.

\section{Conclusions}

Our results showed both inter- and intra-estuarine differences in OCPs and PCBs concentrations in $L$. culveri tissues. Inter-estuarine differences and great sediment-polychaete relationships with some OCPs and PCBs compounds allow establishing the feasibility of the use of this species as a biomonitor of these chemicals. Intra-estuarine spatial differences observed in $L$. culveri also promote the use of this species to the assessment of the local impact of this type of POPs from the same estuarine system. In this sense, seasonal and body-size differences observed in OCPs/PCBs tissue levels reveal the importance of these factors for intra-estuarine POPs monitoring using this key estuarine species.

\section{Acknowledgements}

This works was supported by ANPCyT of Argentina of Dr. Mauricio Díaz-Jaramillo, (PICT-2510) and partially funded by CONICET (PIP0498). We would also like to thank to Francesca Mitton, Agustina de Marco and Instituto de Investigaciones Marinas y Costeras, IIMyCCONICET for the support during the laboratory assays and field sampling.

\section{Appendix A. Supplementary data}

Supplementary data to this article can be found online at https:// doi.org/10.1016/j.marpolbul.2018.09.008.

\section{References}

Ahrens, M.J., Hertz, J., Lamoureux, E.M., et al., 2001. The effect of body size on digestive chemistry and absorption efficiencies of food and sediment-bound organic contaminants in Nereis succinea (Polychaeta). J. Exp. Mar. Biol. Ecol. 263, 185-209. https://doi.org/10.1016/S0022-0981(01)00305-7.

Beltrame, M.O., De Marco, S.G., Marcovecchio, J.E., 2009. Dissolved and particulate heavy metals distribution in coastal lagoons. A case study from Mar Chiquita Lagoon, Argentina. Estuar. Coast. Shelf Sci. 85, 45-56. https://doi.org/10.1016/j.ecss.2009. 04.027.

Bodin, N., Le Loc'h, F., Caisey, X., et al., 2008. Congener-specific accumulation and trophic transfer of polychlorinated biphenyls in spider crab food webs revealed by stable isotope analysis. Environ. Pollut. 151, 252-261. https://doi.org/10.1016/j. envpol.2007.01.051.

Burreau, S., Zebühr, Y., Broman, D., Ishaq, R., 2004. Biomagnification of polychlorinated biphenyls (PCBs) and polybrominated diphenylethers (PBDEs) studied in pike (Esox lucius), perch (Perca fluviatilis) and roach (Rutilus rutilus) from the Baltic Sea.

Chemosphere 55, 1043-1052. https://doi.org/10.1016/j.chemosphere.2003.12.018.

Colombo, J.C., Cappelletti, N., Barreda, A., et al., 2005. Vertical fluxes and accumulation of PCBs in coastal sediments of the Rio de la Plata estuary, Argentina. Chemosphere 61, 1345-1357. https://doi.org/10.1016/j.chemosphere.2005.03.090.

De Jesús-flores, C., Salazar-González, S.A., Salazar-Vallejo, S.I., 2016. Morphological distinction between estuarine polychaetes: Laeonereis culveri and L. nota (Phyllodocida: Nereididae). Rev. Biol. Trop. 64, 205-217.

Delucchi, F., Tombesi, N.B., Freije, R.H., Marcovecchio, J.E., 2007. Butyltin compounds in sediments of the Bahía Blanca estuary, Argentina. Environ. Monit. Assess. 132, 445-451. https://doi.org/10.1007/s10661-006-9547-4. 
Díaz-Jaramillo, M., Sandoval, N., Barra, R., et al., 2015. Spatio-temporal population and reproductive responses in Perinereis gualpensis (Polychaeta: Nereididae) from estuaries under different anthropogenic influences. Chem. Ecol. 1-12. https://doi.org/10. 1080/02757540.2015.1022535.

Díaz-Jaramillo, M., Miglioranza, K.S.B., Gonzalez, M., et al., 2016. Uptake, metabolism and sub-lethal effects of BDE-47 in two estuarine invertebrates with different trophic positions. Environ. Pollut. 213, 608-617. https://doi.org/10.1016/j.envpol.2016.03. 009.

Durou, C., Smith, B.D., Roméo, M., et al., 2007. From biomarkers to population responses in Nereis diversicolor: assessment of stress in estuarine ecosystems. Ecotoxicol. Environ. Saf. 66, 402-411. https://doi.org/10.1016/j.ecoenv.2006.02.016.

Goerke, H., Weber, K., 1990. Population-dependent elimination of various polychlorinated biphenyls in Nereis diversicolor (Polychaeta). Mar. Environ. Res. 29, 205-226. https://doi.org/10.1016/0141-1136(90)90034-L.

Goerke, H., Weber, K., 2001. Species-specific elimination of polychlorinated biphenyls in estuarine animals and its impact on residue patterns. Mar. Environ. Res. 51, 131-149. https://doi.org/10.1016/S0141-1136(00)00036-2.

Gonzalez, M., Miglioranza, K.S.B., Grondona, S.I., et al., 2013. Organic pollutant levels in an agricultural watershed: the importance of analyzing multiple matrices for assessing stream water pollution. Environ. Sci.: Processes Impacts 15, 739. https://doi. org/10.1039/c3em30882k.

Greenfield, B.K., Davis, J.A., Fairey, R., et al., 2005. Seasonal, interannual, and long-term variation in sport fish contamination, San Francisco Bay. Sci. Total Environ. 336, 25-43. https://doi.org/10.1016/j.scitotenv.2004.05.023.

Hong, S.H., Kannan, N., Yim, U.H., et al., 2011. Polychlorinatedbiphenyls (PCBs) in a benthic ecosystem in Gwangyang Bay, South Korea. Mar. Pollut. Bull. 62, 2863-2868. https://doi.org/10.1016/j.marpolbul.2011.09.005.

Kannan, N., Reusch, T.B.H., Schulz-Bull, D.E., et al., 1995. Chlorobiphenyls: model compounds for metabolism in food chain organisms and their potential use as ecotoxicological stress indicators by application of the metabolic slope concept. Environ. Sci. Technol. 29, 1851-1859. https://doi.org/10.1021/es00007a024.

Keith, L.H., Crummett, W., Deegan, J., et al., 1983. Principles of Environmental Analysis Society. pp. 2210-2218.

Kopprio, G.A., Biancalana, F., Fricke, A., et al., 2015. Global change effects on biogeochemical processes of Argentinian estuaries: an overview of vulnerabilities and ecohydrological adaptive outlooks. Mar. Pollut. Bull. 91, 554-562. https://doi.org/ 10.1016/j.marpolbul.2014.08.021.

Li, H., Wang, F., You, J., 2017. Bioaccumulation of sediment-bound dichlorodiphenyltrichloroethane and heavy metals in benthic polychaete, Nereis succinea from a typical mariculture zone in South China. Mar. Pollut. Bull. 124, 1040-1047. https://doi.org/10.1016/j.marpolbul.2016.11.048.

Lin, T., Hu, Z., Zhang, G., et al., 2009. Levels and mass burden of DDTs in sediments from fishing harbors: The importance of DDT-containing antifouling paint to the coastal environment of China. Environ. Sci. Technol. 43, 8033-8038. https://doi.org/10. 1021/es901827b.

Lotufo, G.R., Landrum, P.F., Gedeon, M.L., et al., 2000. Comparative toxicity and toxicokinetics of DDT and its major metabolites in freshwater amphipods. Environ. Toxicol. Chem. 19, 368-379. https://doi.org/10.1002/etc.5620190217.

Luis, O.J., Passos, A.M., 1995. Seasonal changes in lipid content and composition of the polychaete Nereis (Hediste) diversicolor. Comp. Biochem. Physiol. B Biochem. Mol. Biol. 111, 579-586. https://doi.org/10.1016/0305-0491(95)00029-8.

Lupi, L., Miglioranza, K.S.B., Aparicio, V.C., et al., 2015. Occurrence of glyphosate and AMPA in an agricultural watershed from the southeastern region of Argentina. Sci. Total Environ. 536, 687-694. https://doi.org/10.1016/j.scitotenv.2015.07.090.

Marcovecchio, J., Ferrer, L., 2005. Distribution and geochemical partitioning of heavy metals in sediments of the Bahía Blanca estuary, Argentina. J. Coast. Res. 214, 826-834. https://doi.org/10.2112/014-NIS.1.

Menone, M.L., Aizpún De Moreno, J.E., Moreno, V.J., et al., 2001. Organochlorine pesticides and PCBs in a southern Atlantic coastal lagoon watershed, Argentina. Arch. Environ. Contam. Toxicol. 40, 355-362. https://doi.org/10.1007/s002440010183.

Menone, M.L., Miglioranza, K.S.B., Botto, F., et al., 2006. Field accumulative behavior of organochlorine pesticides. The role of crabs and sediment characteristics in coastal environments. Mar. Pollut. Bull. 52, 1717-1724. https://doi.org/10.1016/j. marpolbul.2006.07.005.
Metcalfe, T.L., Metcalfe, C.D., 1997. The trophodynamics of PCBs, including mono- and non-orthocongeners, in the food web of North-Central Lake Ontario. Sci. Total Environ. 201, 245-272. https://doi.org/10.1016/S0048-9697(97)84061-2.

Miglioranza, K.S.B., Aizpún De Moreno, J.E., Moreno, V.J., 2003. Dynamics of organochlorine pesticides in soils from a southeastern region of Argentina. Environ. Toxicol Chem. 712-717.

Milun, V., Grgas, D., Dragičević, T.L., 2016. Assessment of PCB and chlorinated pesticide accumulation in mussels at Kaštela Bay (Eastern Adriatic). Sci. Total Environ. 562, 115-127. https://doi.org/10.1016/j.scitotenv.2016.03.133.

Mingorance, M.D., Barahona, E., Fernández-Gálvez, J., 2007. Guidelines for improving organic carbon recovery by the wet oxidation method. Chemosphere 68, 409-413. https://doi.org/10.1016/J.CHEMOSPHERE.2007.01.021.

Nesto, N., Cassin, D., Da Ros, L., 2010. Isthepolychaete, Perinereis rullieri (Pilato 1974), a reliable indicator of PCB and PAH contaminants in coastal sediments? Ecotoxicol Environ. Saf. 73, 143-151. https://doi.org/10.1016/j.ecoenv.2009.09.004.

Nunes, M., Marchand, P., Vernisseau, A., et al., 2011. PCDD/Fs and dioxin-like PCBs in sediment and biota from the Mondego estuary (Portugal). Chemosphere 83, 1345-1352. https://doi.org/10.1016/j.chemosphere.2011.02.081.

Nyberg, E., Faxneld, S., Danielsson, S., et al., 2015. Temporal and spatial trends of PCBs, DDTs, HCHs, and HCB in Swedish marine biota 1969-2012. Ambio 44, 484-497. https://doi.org/10.1007/s13280-015-0673-5.

Olenycz, M., Sokotowski, A., Niewińska, A., et al., 2015. Comparison of PCBs and PAHs levels in European coastal waters using mussels from the Mytilus edulis complex as biomonitors. Oceanologia 57, 196-211. https://doi.org/10.1016/j.oceano.2014.12. 001.

Olsson, A., Valters, K., Burreau, S., 2000. Concentrations of organochlorine substances in relation to fish size and trophic position: a study on perch (Perca fluviatilis L.). Environ. Sci. Technol. 34, 4878-4886. https://doi.org/10.1021/es991400t.

Piccolo, M.C., Perillo, G.E., 1999. The Argentina estuaries: a review. In: Perillo, G.E., Piccolo, M., Pino-Quivira, M. (Eds.), Estuaries of South America. Springer, Berlin, Heidelberg, pp. 101-132. https://doi.org/10.1007/978-3-642-60131-6_6.

Ruus, A., Ugland, K.I., Skaare, J.U., 2002. Influence of trophic position on organochlorine concentrations and compositional patterns in a marine food web. Environ. Toxicol. Chem. 21, 2356-2364. https://doi.org/10.1002/etc.5620211114.

Sardi, A.E., Sandrini-Neto, L., da S. Pereira, L., et al., 2016. Oxidative stress in two tropical species after exposure to diesel oil. Environ. Sci. Pollut. Res. 23, 20952-20962. https://doi.org/10.1007/s11356-016-7280-2.

Silva Barni, M.F., Gonzalez, M., Miglioranza, K.S.B., 2014. Assessment of persistent organic pollutants accumulation and lipid peroxidation in two reproductive stages of wild silverside (Odontesthes bonariensis). Ecotoxicol. Environ. Saf. 99, 45-53. https:// doi.org/10.1016/j.ecoenv.2013.10.012.

Tombesi, N., Pozo, K., Álvarez, M., et al., 2017. Tracking polychlorinated biphenyls (PCBs) and polybrominated diphenylethers (PBDEs) in sediments and soils from the southwest of Buenos Aires Province, Argentina (South eastern part of the GRULAC region). Sci. Total Environ. 575, 1470-1476. https://doi.org/10.1016/j.scitotenv. 2016.10.013.

Van Ael, E., Covaci, A., Blust, R., Bervoets, L., 2012. Persistent organic pollutants in the Scheldt estuary: environmental distribution and bioaccumulation. Environ. Int. 48, 17-27. https://doi.org/10.1016/j.envint.2012.06.017.

Van Ael, E., Covaci, A., Das, K., et al., 2013. Factors influencing the bioaccumulation of persistent organic pollutants in food webs of the Scheldt Estuary. Environ. Sci. Technol. 47, 11221-11231. https://doi.org/10.1021/es400307s.

Viganò, L., Farkas, A., Guzzella, L., et al., 2007. The accumulation levels of PAHs, PCBs and DDTs are related in an inverse way to the size of a benthic amphipod (Echinogammarus stammeri Karaman) in the River Po. Sci. Total Environ. 373, 131-145. https://doi.org/10.1016/j.scitotenv.2006.11.006.

Wang, F., Yuan, Pei Y., You, J., 2015. Biotransformation of dichlorodiphenyltrichloroethane in the benthic polychaete, Nereis succinea: quantitative estimation by analyzing the partitioning of chemicals between gut fluid and lipid. Environ. Toxicol. Chem. 34, 360-368. https://doi.org/10.1002/etc.2811.

Yu, H.Y., Bao, L.J., Liang, Y., Zeng, E.Y., 2011. Field validation of anaerobic degradation pathways for dichlorodiphenyltrichloroethane (DDT) and 13 metabolites in marine sediment cores from China. Environ. Sci. Technol. 45, 5245-5252. https://doi.org/ 10.1021/es200. 